\title{
Role of Literacy on Working Status and Income Expenditure Gap among Senior Citizens in Rural \& Urban Areas of Mirpurkhas
}

Ghulam Qadir Arbab ${ }^{1}$, Nanik Ram ${ }^{2}$, Imdad Ali Khawaja ${ }^{3}$

\begin{abstract}
The rapidly increasing population of older people in developed as well developing countries including Pakistan is a serious concern. As a result senior citizens face problems during their latter part of life. In most of the cases, the senior citizens are forced to continue work for their livelihood due to poverty. But due to the lack of conducive working opportunities they face hurdles in getting suitable work. This study was conducted with the main objective to evaluate difference in the working status and income expenditure gap among literate and illiterate senior citizens. Descriptive method was followed to conduct this study and random sampling technique was used to select the respondents. Close ended questionnaire was used to collect data from 385 male and female senior citizens in the rural and urban areas of district Mirpurkhas. The study found that the literate senior citizens were in better position as compared to illiterate senior citizens. Literate senior citizens has comparative advantage over illiterate senior citizens in getting work resultantly got better monthly income level as compared to illiterate senior citizens. Moreover, the current status of health of literate senior citizens was also better as compared to illiterate senior citizens.
\end{abstract}

Keywords: Senior citizens, older people, income security, living standard, working status, health, income expenditure gap

\section{Introduction}

Ageing is a continuous process of change and an inevitable phenomenon with biological, social and physiological effects on human life. However, due to technological advancement, the life expectancy has increased but it has not stopped people dying. Practically, as people get older, they face challenges. Social perspective is an important part of life that older people face in their latter part of life. Several theories explain the sociological and physiological aspects of ageing i.e. activity theory, continuity theory and disengagement theory. Activity theory occurs when an individual enjoy full day of work and feels satisfied being

\footnotetext{
${ }^{1} \mathrm{PhD}$ scholar, Department of Economics, University of Sindh, Jamshoro

Email: gqarbab@gmail.com

${ }^{2}$ Professor, Department of Economics, University of Sindh, Jamshoro

${ }^{3}$ Assistant Professor, Department of Economics, University of Sindh, Jamshoro
} 
active. Ideally, when people remain physically active, they will remain happy, healthy and in touch with others. Atchley (1989) described that a large proportion of older people continue their activities, social interaction, and living arrangements. This theory is based on two types of continuity i.e. internal and external. Internal continuity refers to personal values, beliefs etc. and external continuity refers to continuity in ones activities, social interaction, and living arrangements etc. (Atchley, 1989). Contrary to these, the disengagement theory outline changes that occur due to old age i.e. either older people voluntarily withdraw or disengage themselves from the social role they were playing before and according to this theory this withdrawal or disengagement is natural and beneficial to society (Atchley, 1989).

The rapidly increasing population of older people in developed as well developing countries is a serious concern all across the world (UNFPA, 2012). The demographic imbalance is a serious alert to the entire world, where Pakistan, too stands to no exception. On an average two persons are crossing their age over 60 years per second (UNFPA, 2012) and adding around 58 million older people in global population each year. Currently, out of nine persons one person is older person who is projected to increase to five older people among nine person by the year 2050 (UNFPA, 2012). Pakistan, with a population of over 211.17 million is the $5^{\text {th }}$ most populous country of the world (GoP, 2020). Its population is growing at an annual rate of 1.95 per cent, which is one of the highest in the region as well as in the world. The population of the country in the age group of 15-64 years is 61.4 percent, followed by 12.1 percent of the population is in between the age group of 0-4 years and remaining 22.1 percent in the 5-14 years age group (GoP 2020).

Generally, older people are also known as senior citizens but there is no internationally recognised definition of old age, but UN has agreed cut off age of 60 years and above as older person (UN 2002). In most of the developed countries consider the age of 65 years as a definition of 'senior citizen, but in most of the developing countries 60 years age is considered as definition of older person (UN 2002). In Pakistan 60 years age is considered as the age of retirement and its benefits. Moreover, the approved senior citizens Act of Sindh (GoS, 2016), Khyber Pakhtunkhwa Senior Citizens Bill (GoKP, 2014), Balochistan Senior Citizens Bill (GoB 2017), and Islamabad Capital Territory Areas bill (GoP, 2017) also consider 60 years as definition of senior citizen. Collins English Dictionary defines that, "a senior citizen is an older people who has retired or receives an old age pension" (Collins 2019). Oxford Dictionary defines 'senior citizen' as "an elderly person, especially an old-age pensioner" (Oxford 2019). The banks in Pakistan also consider 60 years as age for benefits of senior citizens 
(Summit Bank, 2019). Keeping in view these definitions, this study has considered 60 years and above aged men and women as senior citizens.

\subsection{Statement of the Problem}

In most of the developing countries including Pakistan, there is no old age income security except for a small quantity of those who retired from government or corporate private sector jobs and getting pension. Therefore, senior citizens (male and female) are forced to continue working even in their old age which is considered for rest and recreation. However, male older people get some work in their old age but women either are not allowed to work or they do not get work in their old age. As a result, they are completely dependent on their families for their nutrition and health needs. Those women who became widows in their old age, their hardship increase - even some older women prefer to work having no other way to survive. Unfortunately, they are underpaid because of their age and gender. The older people mostly face serious problems either in getting work or continuing the work mainly due to their deteriorating health conditions. Therefore, there is tendency that the older people will get lower wages as compared to healthy people. As a result, the older people are felt as a burden on poor households as they themselves strive for their livelihood.

Pakistan was ranked at the lowest on an overall basis among 96 countries in Global AgeWatch Index (HelpAge International, 2015). The AgeWatch Index measures performance of countries in four main domains including income security, health, and capability and enabling environment. In the domain of income security, Pakistan was ranked at 95 mainly due to lower pension coverage to around $2 \%$ to older people who worked in formal sector. Whereas, majority of workers from informal sector including agriculture is not secured. However, Employees Old-Age Benefits Institution (EOBI) has started a contributory pension to private sector but it is available to limited people working in corporate sector. Moreover, in another domain of 'health' Pakistan was ranked at 78 among 96 countries assessed under the AgeWatch in 'Health' domain. Pakistan performed fairly well under this domain as compared to income security mainly due to ever improving health facilities. However, still there is no specific health coverage to senior citizens. Senior citizen aged 60 can expect to live 17 more years out of which 13.8 years he/she will have to have good health (HelpAge International, 2015).

Every person passes through different stages over a period of time in life from childhood to older age. These stages invariably involve different roles and responsibilities. Starting life from childhood dependency, a person strives hard to support back to his/her family in youth age. Unfortunately, in most of the world due to poverty, one has to work entire life for livelihood. However, after 60 years 
of age, mostly people take rest in their life and enjoy the remaining life with their children and grand-children. But due to poverty, older people are forced to continue working.

\subsection{Objectives of the Study}

The overall objectives of the study were to evaluate the livelihood opportunities and income of senior citizens in the study area in order to figure out the difference in between their income and expenditure and suggest measures for betterment of senior citizens.

\section{Literature Review}

Ashique and Asad (2017) found that the increasing poverty has led families to compromise on the needs of the senior citizens. However, there is some support available in the form of old age homes but still the services provided in these homes are not according to the needs of the senior citizens.

Zaidi et al (2018), in their study found that most of the elder people lack access to basic standard of living including house, clean water, health services, and nutritious food. The study found that older people intend to work in their old age not only to earn money but also to keep them busy and active. Senior citizens face barriers to get work. Therefore, the study suggested that government may invest in several small business enterprises to create working opportunities for older people to ensure income security of older people.

Alam, Ibrar and Khan (2016) found that older people due to their inactive financial role in family, they have been replaced from their position of head of the household which ultimately has reduced their involvement in decision making process in the household. As a result, the older people are forced to live their life in isolation and depression. The study suggested that government must take due care of senior citizens through effective health care and recreation facilities to ensure their active and healthy life free from stress.

Wahab, Mufti, and Khan (2017) in their study on effects of ageing on pension system in Pakistan has studied short and long run relationship in between expenditure of government on pension due to increasing life expectancy and change in older people dependency ratio. The authors opined that this is accepted truth that older people need income security in their latter part of life. The authors found that challenges of pension system revival are felt seriously in developed countries but still developing countries like Pakistan are not taking these issues seriously. The study suggested to make proper planning on ageing and social security issues of senior citizens.

Kudo, Mutisya and Nagao (2015) found that the nature of challenges differ in rural and urban community such as situation of access to basic services in rural areas and problems of shrinking and abandonment of services in cities in 
urban areas. While analysing the challenges at individual level, the research has found that old age population is supposed to face social isolation which can be reduced through communal level linkage initiatives.

Ahmad and Hafeez (2011), in their study on factors affecting social participation of elderly people found that mostly people in their old age are considered as an extra burden on the family and community does not pay attention to engage older people in social as well other interactions at community level. The study found that the socioeconomic status is directly linked with standard of living and social participation of older people for active life.

Gulzar, Zafar, Ahmad and Ali (2008), in their study on socioeconomic problems of senior citizens and effects of these on their lives found that women face more problems in old age as compared to men mainly due to lower access to proper work in old age. The study also found that marital status is an important social factor that reflects the wellbeing of senior citizens. Because life partner at this stage of life plays key role in emotional and provision of care in case of health problems. The study also found that married older people tend to live longer than widowed, however, older persons without any asset or saving face serious problems in their health care, nutrition and social interaction.

Clark et al. (2002) found that income security is the most important problem faced by the senior citizens. They were of the opinion that, however, income earning is foremost problem of most of the poor families but unfortunately little has been done to figure out the problems in order to ensure that problems of senior citizens are resolved in a way that they become free from worries. The authors found that, however, everyone tries to save for the latter part of their life but most of the families in Pakistan cannot save enough for their old age. This leads to their dependency on their families. Therefore, the study suggested corrective measures for income security of senior citizens.

Lubna et al. (2000) in their study found that, however, the senior citizens are taken care by their families with available means but still the majority of the senior citizens informed to the researchers that they intend to continue working but they do not do not get work. The study found that the socio-economic and health status of elderly people is not satisfactory, hence, recommended due attention by the government.

Chesser et al. (2016) in their study on "Health Literacy and Older Adults" found that the education of senior citizens seriously affects the health care awareness. The study found that the senior citizens with low health literacy were experiencing poor physical health condition as compared to literate senior citizens. Based on findings, the study stressed upon creating health care 
awareness among senior citizens that will lead to better health care management and cost saving not only among senior citizens but also to health care systems.

The empirical studies mentioned above emphasis for the betterment of socioeconomic status of the old age/senior citizen to remedying to the access of the basic needs of human by better planning, health care facilities, income, etc. by the state. While, there is difference in between their income sources and expenditure for better livelihood of senior citizens. Moreover, the studies reviewed also lack sufficient discussion on issues related to income earning opportunities for senior citizens based on their literacy level. Therefore, this study was conducted to explore the gaps in the selected areas and suggest future course of actions.

\subsection{Research Design}

\section{Research Methodology}

Descriptive research method was used to conduct this study. Survey method of data collection was used to collect data from the sample senior citizens from selected rural and urban areas of district Mirpurkhas.

\subsection{Population of Study}

This study covered district Mirpurkhas to collect quantitative data from the senior citizens in rural as well as urban areas. District Mirpurkhas was selected mainly due to the reason that the district's main city is divisional head quarter with almost all facilities that an urban area can provide to the inhabitants. Moreover, the migrant workers from adjoining desert areas of district Tharparkar also come in rural areas so this aspect was also considered as an additional opportunity to reach senior citizens from varied cultural backgrounds.

\subsection{Sample and Sampling Technique}

A purposive sample of 385 senior citizens ageing 60 years and above was drawn from rural and urban areas. Random sampling technique was employed using four main stages to select households in the selected district. The first stage involved the clustering of 2 Tehsils (Rural \& Urban) out of 7 Tehsils in the district. These two Tehsils were selected purposively i.e. one from rural areas (Tehsil Sindhri) and one from urban areas (Tehsil Mirpurkhas). In the second stage, two union councils were selected purposively among the union councils in the Tehsil. Resultantly, union council Phuladyoon and Ismail Kumbher were selected from Tehsil Sindhri (rural area) and union council 3 and union council 7 were selected from Tehsil Mirpurkhas (urban area). In the third stage, 8 villages were selected purposively from each union council. Finally, in the fourth stage these villages were visited for data collection. 


\subsection{Instrumentation}

Consultations with senior citizens were conducted in rural and urban areas in order to develop a close ended questionnaire for quantitative data collection from the senior citizens in the selected area. The questionnaire was designed in the English language to collect data related to age, marital status, gender, area, family system, education, income and health of the senior citizens. Likert scale was used in data collection for scaling the responses to indicate the level of agreement from strongly agree to strongly disagree.

\subsection{Data Collection}

In order to grasp the actual situation at grassroots level, the study involved primary data collection directly from the senior citizens above 60 years of age both from rural as well as urban areas of Mirpurkhas district. This helped to understand the current problems being faced by the senior citizens.

\section{Data Analysis and Interpretation}

The quantitative collected from senior citizens was checked, coded and entered in Statistical Package for Social Sciences (SPSS) for analysis and results are presented in this research article.

Table 4.1

Distribution of Respondents by their Age Groups

\begin{tabular}{ccccccc}
\hline Age Group & \multicolumn{2}{c}{ Male } & \multicolumn{2}{c}{ Female } & \multicolumn{2}{c}{ Total } \\
\cline { 2 - 7 } & Number & $\%$ & $\begin{array}{c}\text { Number } \\
\text { Rural }\end{array}$ & Number & $\%$ \\
60-70 Years & 122 & $53 \%$ & 45 & $19 \%$ & 167 & $72 \%$ \\
71-80 Years & 26 & $11 \%$ & 24 & $10 \%$ & 50 & $22 \%$ \\
81-90 Years & 13 & $6 \%$ & 1 & $0.4 \%$ & 14 & $6 \%$ \\
Total & 161 & $70 \%$ & 70 & $30 \%$ & 231 & $100 \%$ \\
& & & Urban & & & \\
60-70 Years & 43 & $28 \%$ & 47 & $31 \%$ & 90 & $58 \%$ \\
$71-80$ Years & 47 & $31 \%$ & 0 & $0 \%$ & 47 & $31 \%$ \\
$81-90$ Years & 17 & $11 \%$ & 0 & $0 \%$ & 17 & $11 \%$ \\
Total & 107 & $69 \%$ & 47 & $31 \%$ & 154 & $100 \%$ \\
Grand Total & 268 & $70 \%$ & 117 & $30 \%$ & 385 & $100 \%$ \\
\hline
\end{tabular}

The data presented in table-4.1 reveals that out of 385 respondents, 231 respondents $(60 \%)$ were from rural areas and $154(40 \%)$ were from urban area. The gender wise breakup of respondents in rural and urban areas reveals that out 
of every 10 respondents $30 \%$ were women both in rural and urban areas. The data on age group of respondents in rural areas shows that $53 \%$ male and $19 \%$ female respondents were from age group of 60 -70 years followed by around $10 \%$ male and female respondents from age group of $71-80$ years. There was little female representation in age group of $81-90$ years as only $0.4 \%$ respondents. On the other hand, female from urban areas were only from age group of $60-70$ years and male respondents belonged to all three age group with higher number of $31 \%$ under the age group of $71-80$ years. The community, while consultations with them, informed that women live in isolation in their old age after 70 years and are not allowed to interact with strange people.

Table 4.2

\section{Distribution of Respondents by their Marital Status}

\begin{tabular}{lcccccc}
\hline \multirow{2}{*}{ Age Group } & \multicolumn{2}{c}{ Male } & \multicolumn{2}{c}{ Female } & \multicolumn{2}{c}{ Total } \\
\cline { 2 - 7 } & Number & $\%$ & $\begin{array}{c}\text { Number } \\
\text { Rural }\end{array}$ & $\%$ & Number & $\%$ \\
Married & 89 & $39 \%$ & 23 & $10 \%$ & 112 & $48 \%$ \\
Un-Married & 7 & $3 \%$ & 0 & $0 \%$ & 7 & $3 \%$ \\
Divorced & 0 & $0 \%$ & 0 & $0 \%$ & 0 & $0 \%$ \\
Separated & 0 & $0 \%$ & 0 & $0 \%$ & 0 & $0 \%$ \\
Widow & 65 & $28 \%$ & 47 & $20 \%$ & 112 & $48 \%$ \\
\multicolumn{1}{c}{ Total } & 161 & $70 \%$ & 70 & $30 \%$ & 231 & $100 \%$ \\
Married & 51 & $33 \%$ & 13 & $8 \%$ & 64 & $42 \%$ \\
Un-Married & 5 & $3 \%$ & 0 & $0 \%$ & 5 & $3 \%$ \\
Divorced & 7 & $5 \%$ & 3 & $2 \%$ & 10 & $6 \%$ \\
Separated & 9 & $6 \%$ & 4 & $3 \%$ & 13 & $8 \%$ \\
Widow & 35 & $23 \%$ & 27 & $18 \%$ & 62 & $40 \%$ \\
$\quad$ Total & 107 & $69 \%$ & 47 & $31 \%$ & 154 & $100 \%$ \\
Grand Total & 268 & $70 \%$ & 117 & $30 \%$ & 385 & $100 \%$ \\
\hline \multicolumn{2}{c}{ The data } & on marital status of respondents & shows that out of
\end{tabular}

231respondents from rural areas, 39\% male senior citizens were married, $3 \%$ unmarried, and $28 \%$ were widowers. Whereas, the data of female senior citizens from rural areas show that $10 \%$ were married and $20 \%$ were widows. Same way from urban areas, 33\% male senior citizens were married, followed by $3 \%$ unmarried, $5 \%$ divorced, $6 \%$ separated and $23 \%$ widowers. On the other hand, $8 \%$ female senior citizens reported being married, $2 \%$ divorced, $3 \%$ separated and $18 \%$ widows. The data clearly shows that female senior citizens had married status on lower side as compared to male senior citizens both in rural and urban areas. 
Table 4.3

Distribution of Respondents by their Education

\begin{tabular}{|c|c|c|c|c|c|c|c|c|c|}
\hline \multirow[t]{2}{*}{ Education } & \multicolumn{4}{|c|}{ Rural } & \multicolumn{4}{|c|}{ Urban } & \multirow[t]{2}{*}{ Total } \\
\hline & Male & $\%$ & Female & $\%$ & Male & $\%$ & Female & $\%$ & \\
\hline Primary & 37 & 61 & 2 & 13 & 11 & $47 \%$ & 5 & 72 & 55 \\
\hline Middle & 15 & $\%$ & 0 & $\%$ & 17 & & 3 & $\%$ & 35 \\
\hline Matric & 9 & & 0 & & 13 & & 2 & & 24 \\
\hline Intermediate & 3 & & 0 & & 11 & & 1 & & 15 \\
\hline Graduate & 17 & & 0 & & 15 & & & & 32 \\
\hline Masters & 3 & & 0 & & 3 & & & & 6 \\
\hline Above PG & 0 & & 0 & & 2 & & & & 2 \\
\hline Illiterate & 62 & 39 & 61 & 87 & 30 & $53 \%$ & 33 & 28 & 186 \\
\hline $\begin{array}{l}\text { Under } \\
\text { Primary }\end{array}$ & 15 & $\%$ & 7 & $\%$ & 5 & & 3 & $\%$ & 30 \\
\hline Total & 161 & $\begin{array}{c}100 \\
\%\end{array}$ & 70 & $\begin{array}{c}100 \\
\%\end{array}$ & 107 & $\begin{array}{c}100 \\
\%\end{array}$ & 47 & $\begin{array}{c}100 \\
\%\end{array}$ & 385 \\
\hline
\end{tabular}

The literacy rate shown in table 4.3 presents a positive picture both for rural and urban areas where majority of $61 \%$ male from rural areas and $72 \%$ male from urban areas reported being literate. On the other hand, the female literacy was comparatively higher in urban areas at $28 \%$ as against $13 \%$ in rural areas.

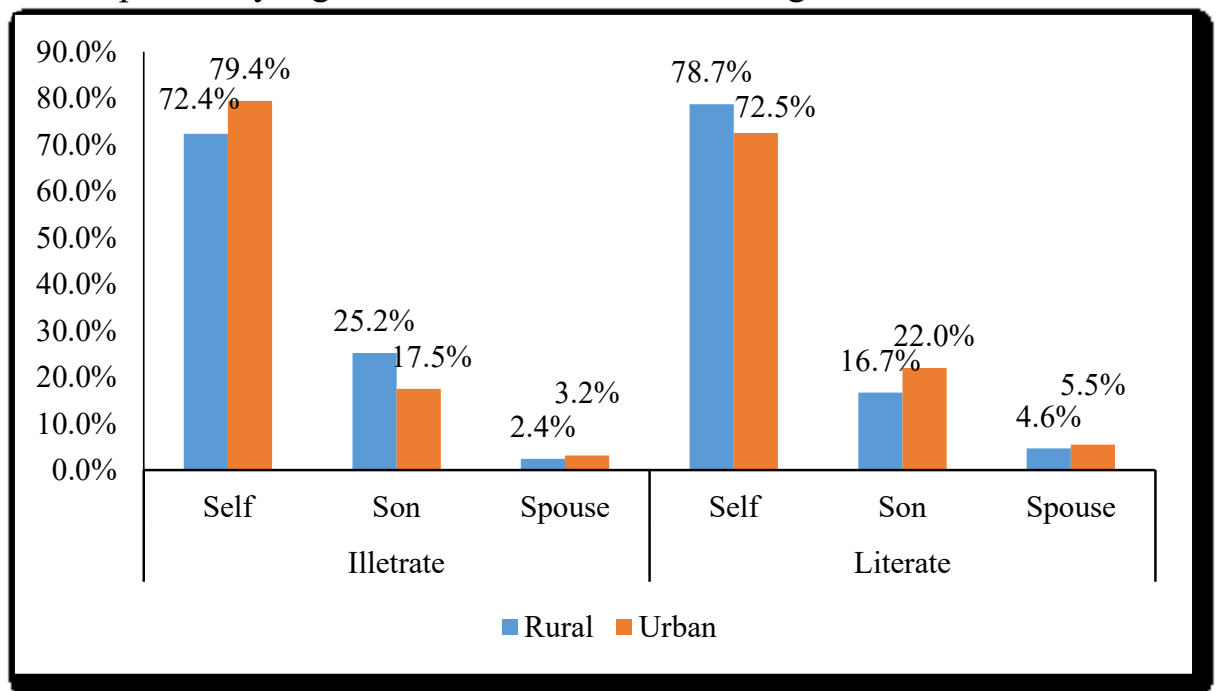

Figure 4.1 Head of the Household 
The results on head of the household presented in fig 4.1 shows different picture for literate and illiterate senior citizens. The majority of more than $70 \%$ senior citizens reported themselves 'Self' being the head of their household followed by son. The number of literate senior citizens as head of the household from rural areas was higher as reported by $78.7 \%$ as compared to $72.4 \%$ illiterate senior citizens. On the other hand, this number was high in illiterate senior citizens from urban areas as reported by $79.4 \%$ as compared to $72.5 \%$ literate senior citizens from urban areas being head of their household.

Family system has direct impact on income security and wellbeing of senior citizens. Hence, under this study, the senior citizens were asked about the family system they are living. Normally, there are two types of family system in rural and urban areas i.e. joint and nuclear family. Generally, due to poverty and migration to urban areas, the nuclear family system is on increasing trend as shown in the figure given below.

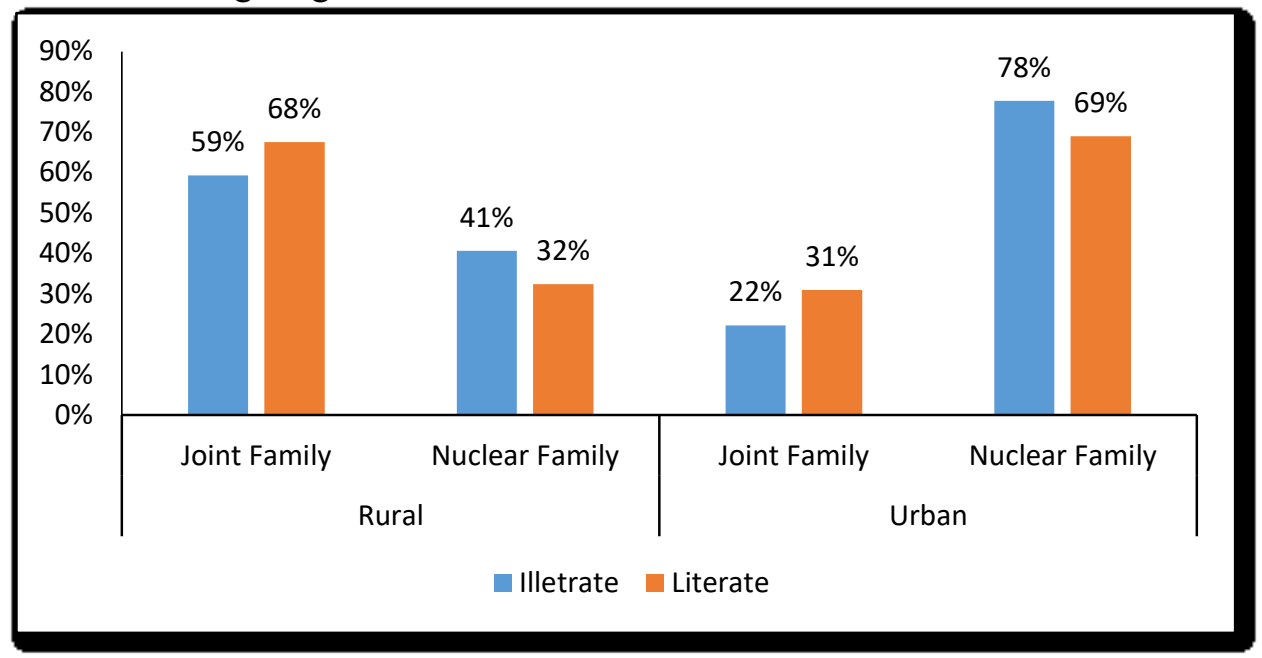

Figure 4.2 Respondents by their Family System

The data related to family system in the households of senior citizens shown in fig 4.2 reveals that on an overall basis the joint family system in rural areas and nuclear family system was higher in urban areas in literate as well as illiterate respondents' families. However, the number of nuclear family system in urban areas was slightly lower in literate families i.e. $69 \%$ as compared to $78 \%$ in illiterate families.

Working status mainly depend on available working opportunities, wage structure and enabling environment. With increased age, the senior citizens prefer to work with less physical involvement. Under this study, the senior citizens were 
inquired about their current working status and responses given by senior citizens are presented in the fig 4.3 below.

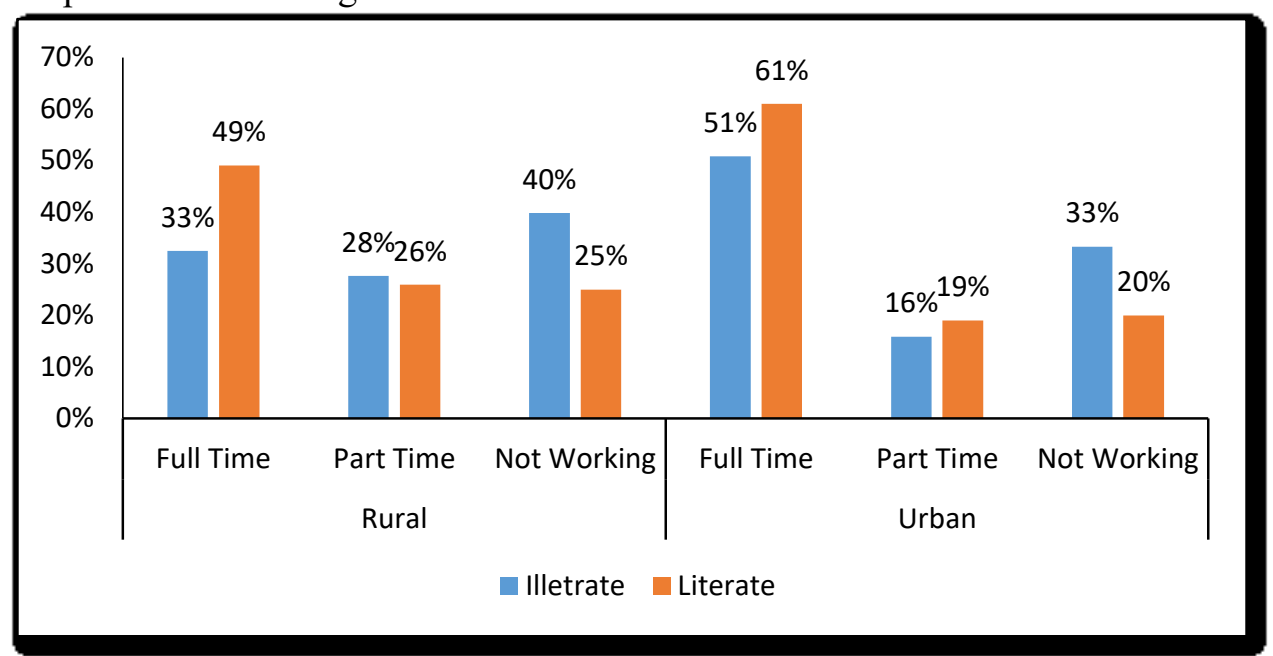

Figure 4.3 Current Working Status of Respondents

The data results related to working status of senior citizens from rural and urban areas reveals that the number of full time working senior citizens were higher among literate senior citizens in rural (49\%) as well as urban areas (61\%). Moreover, the number of full time working reported by illiterate senior citizens was also higher in urban areas $51 \%$ against $33 \%$ in rural areas.

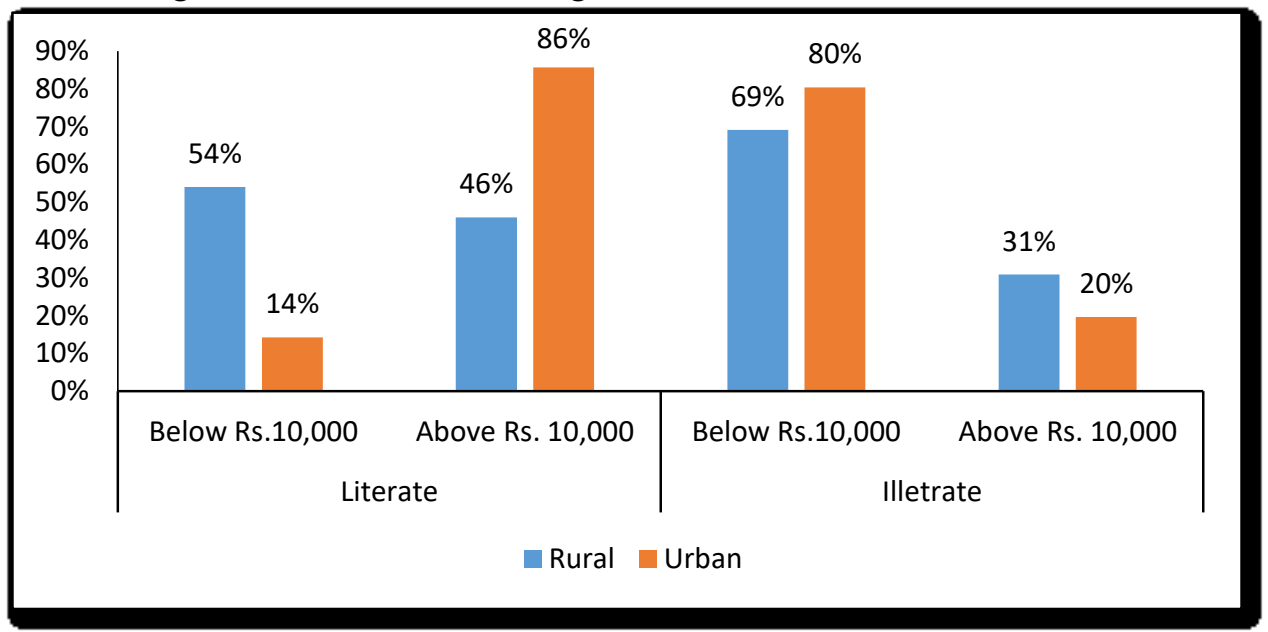

Figure 4.4 Monthly Income 
The data related to monthly income of the senior citizens presented in fig 4.4 reveals that income of literate senior citizens above Rs. 10,000 per month was higher in rural (46\%) as well as urban (86\%) areas. On the other hand, 69\% illiterate senior citizens from rural areas and $80 \%$ illiterate senior citizens from urban areas reported that their income is less than Rs. 10,000 per month.

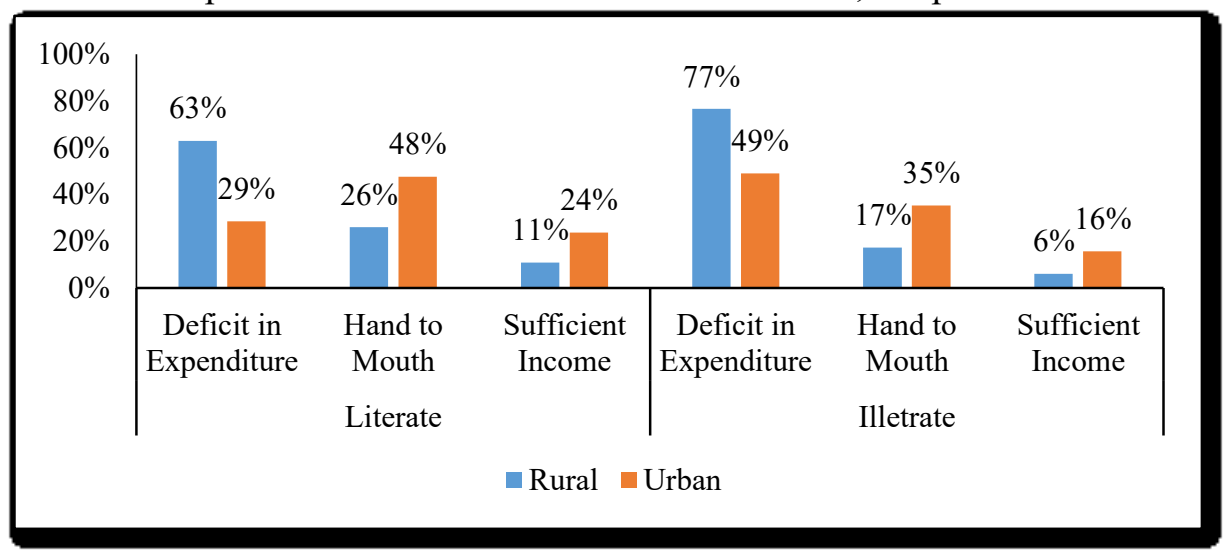

\section{Figure 4.5 Income Sufficiency}

The data related to income expenditure gap among senior citizens in rural and urban areas shown in fig 4.5 reveals that, however, majority of senior citizens from rural and urban areas reported that their income is not sufficient but the situation of literate senior citizens was comparatively better. While reporting income sufficiency $11 \%$ literate senior citizens from rural areas and $24 \%$ literate senior citizens from urban areas informed that their income is sufficient as compared to $6 \%$ and $16 \%$ illiterate senior citizens from rural and urban areas respectively.

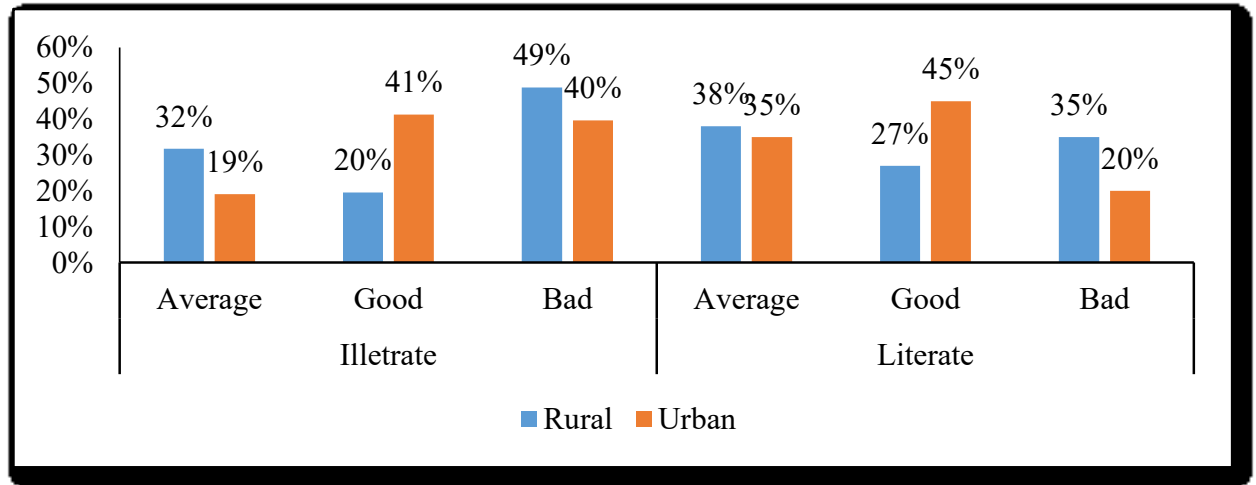

Figure 4.6 Current Health Status 
The status of health of senior citizens is an important factor in their latter part of life. The results presented in fig 4.6 reveals that, however, on an overall basis the current status of health of majority of senior citizens was either bad or average in rural and urban areas, but the situation of literate senior citizens was comparatively better. The data shows that $27 \%$ literate senior citizens from rural and $45 \%$ senior citizens from urban areas reported that their health is good as compared $20 \%$ from illiterate senior citizens from rural and $41 \%$ illiterate senior citizens from urban areas.

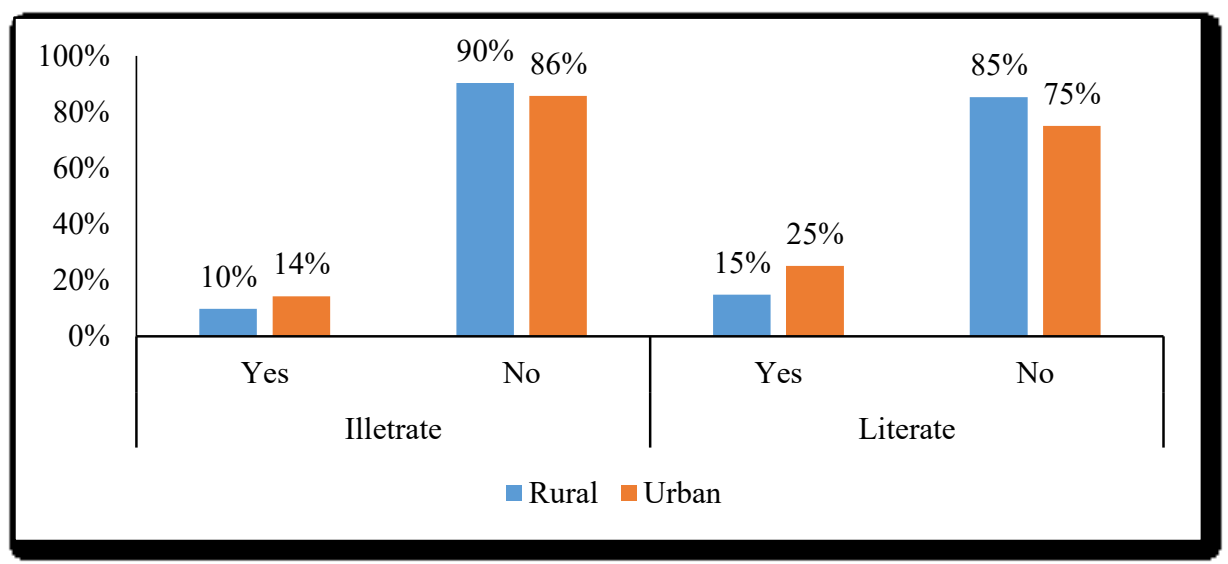

Figure 4.7 Getting Health Services

The results of status on getting health care services presented in fig 4.7 reveals that, however, on an overall basis the majority of senior citizens from rural and urban areas reported that they do not get proper health care services as and when needed by them. But the situation of getting these services was comparatively better among literate senior citizens as reported by $15 \%$ senior citizens from rural and $25 \%$ from urban areas. Whereas, this number was lower among illiterate senior citizens i.e. 10\% from rural areas and 14\% from urban areas. 


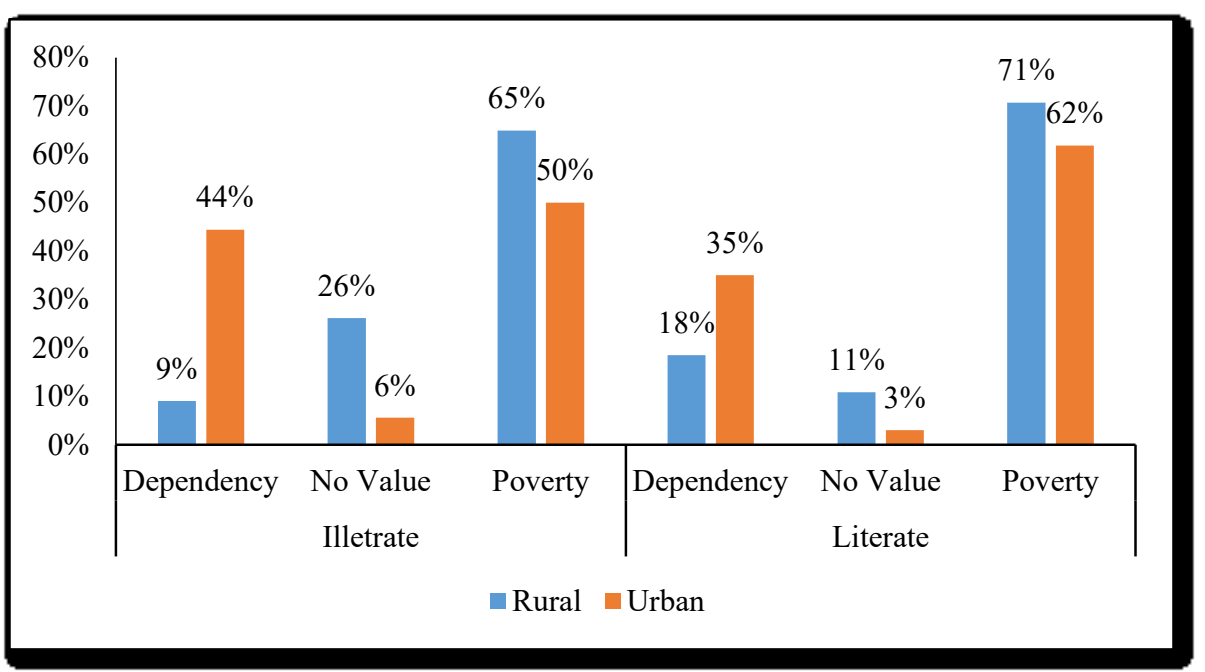

Figure 4.8 Reasons for not getting Health Care Services

The data related to reasons for not getting proper health care presented in fig 4.8 shows mixed trends. Poverty was reported as main reason for not getting health care services by literate as well as illiterate senior citizens from rural and urban areas. The serious issues of ignorance due to dependency and no value of senior citizens in the family were also reported by the senior citizens. But the situation among literate senior citizens was comparatively better as only $11 \%$ senior citizens from rural and 3\% senior citizens from urban areas informed that they do not get proper health care due to 'No Value' in the family. Whereas, a slightly higher percentage of $26 \%$ illiterate senior citizens from rural and $6 \%$ illiterate senior citizens from urban areas informed that they do not get proper health care due to 'No Value' in the family.

\section{Discussion}

The results of this study reveal that due to insufficient income, the senior citizens are forced to continue work in old age. The literature review reveals that mostly the senior citizens are considered burden on the family and community (Ahmad \& Hafeez, 2011) and due to increasing poverty the needs of the senior citizens are compromised (Ashique \& Asad, 2017). Therefore, the senior citizens are forced to work, but they face problem in getting suitable work according to their health and physical condition (Lubna, Zaki \& Muhammad, 2000). Moreover, senior citizens continue working in old age not only to earn money but also to keep them active (Zaidi et al., 2018). Finally, the level of literacy plays an 
important role in embracing the health care awareness in old age (Chesser, Keene, Smothers \& Rogers, 2016).

The results of the data analysis reveal that on an overall basis the literate senior citizens were fairly better as compared to illiterate senior citizens in rural as well as urban areas. While responding to question about reasons if older people do not get proper health care attention from their family, poverty was reported as main reason for not getting health care services by literate as well as illiterate senior citizens from rural and urban areas. The serious issues of ignorance due to dependency and no value of senior citizens in the family was also reported by the senior citizens. But the situation among literate senior citizens was comparatively better as only $11 \%$ senior citizens from rural and $3 \%$ senior citizens from urban areas informed that they do not get proper health care due to 'No Value' in the family. Whereas, a slightly higher percentage of $26 \%$ illiterate senior citizens from rural and 6\% illiterate senior citizens from urban areas informed that they do not get proper health care due to 'No Value' in the family.

The findings on working status show that the urban areas have better working opportunities as $61 \%$ literate and $51 \%$ illiterate senior citizens reported working on full time basis from urban areas. The literate senior citizens were in better position by earning more monthly income from their work as compared to income of illiterate senior citizens in rural and urban areas. Resultantly, majority of senior citizens reported that their income is not sufficient to meet their expenses except $11 \%$ literate senior citizens from rural areas and $24 \%$ literate senior citizens from urban areas who reported their income sufficiency.

\section{Conclusions}

1. On an overall basis, the literate senior citizens were in better position as compared to illiterate senior citizens. Literate senior citizens has comparative advantage over illiterate senior citizens in getting work. Moreover, literate senior citizens also reported better monthly income level as compared to illiterate senior citizens. Therefore, $11 \%$ literate senior citizens from rural areas and $24 \%$ from urban areas informed that their income is sufficient.

2. The current status of health of literate senior citizens was also better as compared to illiterate senior citizens. However, getting health care services was a big challenge and while counting on reasons, the majority reported poverty as main reason for not getting proper health care followed by reason of old age dependency. 


\section{Recommendations}

1. It is suggested to create conducive working opportunities for the senior citizens with focus on creating better opportunities for illiterate senior citizens.

2. Special attention may be given to create working opportunities for female senior citizens.

3. Adult literacy programmes may also be introduced in order to enable senior citizens to easily understand the age related health awareness tips.

\section{References}

Ahmad, K., \& Hafeez, M., (2011). Factors Affecting Social Participation of Elderly People: A Study in Lahore. Journal of Animal and Plant Sciences, 21(2), 283-289.

Alam, A., Ibrar, M., \& Khan, P. (2016). Socio-Economic and Psychological Problems of the Senior Citizens of Pakistan. Peshawar Journal of Psychology and Behavioural Sciences, 2(2), 249-262.

Ashiq, U., \& Asad, A.Z. (2017). The Rising Old Age Problems in Pakistan. Journal of the Research Society of Pakistan, 54(2), 325-332.

Atchley, R. C. (1989). A Continuity Theory of Normal Aging. The Gerontologist, 29, 183-190.

Chesser, A. K., Keene Woods, N., Smothers, K., \& Rogers, N. (2016). Health Literacy and Older Adults: A Systematic Review. Gerontology \& geriatric medicine, 2. doi.org/10.1177/2333721416630492

Clarke, G., Zaman, H., \& Chaudhry, A.G. (2002). Pakistan Ageing Study: Preliminary report on six sites in Punjab: Testing traditional assumptions about family support.

Collins (2019). Definition of Senior Citizen. Accessed from online Collins English Dictionary from https://www.collinsdictionary.com/dictionary/english/senior-citizen

GoB. (2017). Balochistan Senior Citizens Act, 2017 (Bill NO.04 of 2017). Accessed from https://www.balochistan.gov.pk/index.php?option=com_docman\&task=d oc_download\&gid $=7487 \&$ Itemid $=677$ 
GoKP. (2014). The Khyber Pakhtunkhwa Senior Citizens Act 2014. (Act No. XXXV of 2014)". http://kp.gov.pk/uploads/2016/02/6._Senior_Citizens_Act,_2014_.pdf

GoP. (2014). Civil Establishment Code. Islamabad: Pakistan Public Administration Research Center, Management Services Wing, Establishment Division, Islamabad.

GoP. (2017). Economic Survey. Islamabad: Ministry of Finance, Government of Pakistan.

GoP. (2017). Islamabad Capital Territory Senior Citizens Board Act, 2017. Federal Government.

GoP. (2020). Economic Survey. Islamabad: Ministry of Finance, Government of Pakistan.

GoS. (2013). Development Statistics of Sindh. Karachi: Bureau of Statistics, Planning \& Development Department, Government of Sindh.

GoS. (2016). The Sindh Senior Citizens Welfare Act, 2014 (Sindh Act No.XXI of 2016). PAK-2016-L-104998. http://sindhlaws.gov.pk/setup/publications/PUB-15-000030.pdf

Gulzar, F., Zafar, M.I., Ahmad, A., \& Ali, T. (2008). Socio-economic Problems of Senior Citizens and Their Adjustment in Punjab, Pakistan. Pakistan Journal of Agricultural Sciences, 45(1), 138-144.

HelpAge International. (2015). Global AgeWatch Index 2015: Insight Report. London: HelpAge International. http://reports.helpage.org/globalagewatch-index-2015-insight-report.pdf

Kudo, S., Mutisya, E., \& Nagao, M. (2015). Population Aging: An Emerging Research Agenda for Sustainable Development. Social Sciences, MDPI, Open Access Journal, 4(4), 1-27.

Lubna, A. B., Zaki, H., \& Muhammad, I. (2000). Are the Elderly in Pakistan Getting their Due Share in Health Services? Results from a Survey Done in the Pen Urban Communities of Karachi. Journal of Pakistan Medical Association, 50(6), 235-237.

Oxford Dictionary (2019). Definition of Senior Citizen. Accessed from online Oxford Dictionary from https://en.oxforddictionaries.com/definition/senior_citizen 
Summit Bank (2019). Senior Citizens' Definition. Accessed from http://summitbank.com.pk/index.php/deposit-products/summit-seniorcitizen-account/

UNFPA. (2012). Ageing in the Twenty-First Century: A Celebration and A Challenge. New York: United Nations Population Fund (UNFPA), New York, and HelpAge International, London.

Wahab, M., Mufti, O., \& Khan, M.A. (2017). The Effects of Population Ageing on the Public Pension System in Pakistan. Abasyn Journal of Social Sciences. 10, 252-269.

Zaidi, A., Stefanoni, S., Khalil, H., Williamson, C., Meez, S., Qureshi, W., \& Swindale, O. (2018). Moving from the Margins. Promoting and Protecting the Rights of Older Persons in Pakistan. Islamabad: British Council \& HelpAge International Pakistan (Un-published report).

\section{Citation of this Article:}

Arbab, G. Q., Ram, N., \& Khawaja, I. A. (2020).Role of Literacy on Working Status and Income Expenditure Gap among Senior Citizens in Rural \& Urban Areas of District Mirpurkhas. International Journal of Innovation in Teaching and Learning (IJITL), 6(1), 104-121. 